DOI https://doi.org/10.36059/978-966-397-225-1-7

\title{
THE ART OF THE BOOK: HISTORY AND PRESENT
}

\section{Karakoz Olena}

\section{INTRODUCTION}

In the history of mental development of mankind, there are three main points, three stages: the ability to speak, the art of writing, the art of book printing. The origins of the handwritten word are extremely important for every nation because it is evidence of the culture of the nation, its role in the development of civilization. The book is one of the most important achievements of a human, and book culture is a characteristic way of cultivating his abilities in the conditions of industrial society. The development of modern communication technologies, the interaction of cultures involves creating of new approaches to the development of the science of books and book culture, as today the study, preservation and use of books is the basis for the development of the industry.

The rapid development of the digital age dictates new conditions for the art of printing books. The culture of books, the culture of reading, the art of books are gaining relevance, especially in recent times, when we see some intensification of book publishing. Today in bookstores, exhibitions, fairs, libraries there is a large number of different topics, purpose, style of books, printed by both highly reputable publishers with age-old traditions and the latest publishing structures that are rapidly spreading modern technology and the latest vision of traditional book among the readership. Therefore, the issue of the analysis of publications culture, the quality of editorial and publishing processing, artistic and technical design and printing and, in particular, awareness of the priority of the book as a phenomenon of the national cultural process is relevant.

Each book is a real work of art, with a special, endowed only with its artistic charm. Until the twentieth century, illustrations were combined with a book block, which had the traditional form of a code and was unchanged, but then designers were able to offer a variety of new designs of the book, conducted experiments with techniques of typing, printing, bookbinding. The best publications always combine the painstaking work of an artist and a writer.

Manuscripts were illustrated with the technique of miniature painting with a pen, paints, and gold. After the invention of book printing, a new stage of development comes for illustrating. For example, during the Renaissance, illustration occupies an equivalent place with text (the page of 
the engraving alternates with the page of the set) and is distinguished by the clarity of the composition, simplicity and conventionality of figurative solutions, the use of allegories and emblems.

The art of book illustration flourished in the nineteenth century when illustrations to works were published separately, in the form of albums. And although in the first decades of the twentieth century there was an opinion about the inexpediency of the artistic design of the book, in the modern art of book printing, illustration continues to occupy a prominent place.

Despite the spread of modern channels of communication (radio, television, Internet), the book remains a means of influence and a formative factor in the worldview of a man. Today, publishers conduct various experiments to draw attention to the book, popularize reading, which results in the emergence of unique book forms and literary projects (gamebooks, books, mobile applications, augmented reality books, theatre books, etc.).

The widespread use of multimedia technologies involves not only the implementation of new artistic ideas but also the creation of independent objects - multimedia / interactive books using all multimedia formats. That is a new step in the development of innovative technologies in the book space.

\section{The Art of the Book: from Manuscript to Print}

The existence of a universal theory of books and book culture is difficult, because the book for centuries served as the main comprehensive means of social communication in the spiritual life of society, satisfied the multifaceted functions.

For example, here are just a few questions that characterize the book culture of a particular era and require an additional study on specific samples. In particular, the researchers note the richness of the design of domestic large-format Cyrillic old prints and, at the same time, the restraint of ornamentation, only the framing of titles for journalistic books of smaller size and format, as well as for publications printed in Ukrainian printing houses in Latin, in fact, as it was established in the Western European press.

Here is a great connection with the subject of books. The linguistic realities of those times require more careful study. Simultaneous publication, sometimes in the same printing houses, of works in different languages and fonts: Church Slavonic, Old Ukrainian, Polish, Latin, and later, at the end of the 18th century, in Russian in the civil font is also a reflection of the book culture of a certain era.

Book culture was affected by censorship, beginning with the decree of Peter the Great in 1720, which forbade Ukrainian printing houses to publish secular books, as well as new books of religious content, and "in order there 
was no difference and no special dialect in them." In general, the book of the eighteenth century, in our opinion in comparison with the "golden age" of Ukrainian book publishing of the seventeenth century, is researched insufficiently.

Manuscript book and manuscript-book culture are correlated as a fact and a factor of the culture of a certain historical epic, as a separate and whole, where the manuscript book is a partial, but the system-forming phenomenon of manuscript-book culture.

The manuscript book is a monument of material and spiritual culture, which synthesizes through written sources (mostly narrative) included in it, primarily knowledge acquired by mankind and characterizes science, literature, education and art, the religious culture of certain historical periods. At the same time, the manuscript book itself is a historical fact and a qualitatively separate source on the history of book culture, which contains knowledge about the development of the book as a phenomenon, its material form, content depending on the texts included in it, and the organization of texts, pages, sections, auxiliary apparatus, writing, the art of decoration and framing, and many others. As a phenomenon of book culture, a manuscript book is, in any case, an individual source, created for a specific purpose and at a certain time by many authors of both works and the material form they have. The book reflected the structure of the society's consciousness, so it is a category of the culture of the manuscript period in its entirety. Today it is a historical fact of culture and its historical source. ${ }^{1}$

The oldest accurately dated manuscript of our ancestors is the Ostromir Gospel (1056-1057). It is quite large in size and volume, characterized by its careful execution; among the decorations, we see three full-page coloured miniatures, screensavers with plant-type ornaments, initials with images of human faces, which testifies to the established traditions of book art of the Kievan Rus era. Another example of literature is the Collection of Sviatoslav (1073) - a high-format book, which consists of 383 articles and extracts on religious, philosophical, historical topics. As for the artistic content, the book is richly decorated, contains 6 miniatures on a full page, made of paints and gold, there are also screensavers, initials, endings. The group portrait of real people - Prince Sviatoslav and his family - is marked by the refinement of colour and original artistic level of performance. The prince is depicted as a

1 Dubrovina L. A. (2016) Rukopysna knyha ta rukopysno-knyzhna kultura: do spivvidnoshennia poniat $\mathrm{u}$ dzhereloznavchomu aspekti [Manuscript book and manuscriptbook culture: the relationship of concepts in the source aspect]. Proceedings of the Biblioteka. Nauka. Komunikatsiia. Formuvannia natsionalnoho informatsiinoho prostoru (Ukraine, Kyiv, October 4-6, 2016) (eds. Popyk V. I., Dubrovina L. A., Horovyi V. M.), Kyiv: Natsionalna biblioteka Ukrainy imeni V. I. Vernadskoho, pp. 128-130. 
middle-aged man, holding a book in his hands. We should pay attention to the peculiarities of the zodiac signs' images on parchment, without soil, for which scientists call it "the first Russian drawing". Kyiv Psalter (1397) is later, but no less impressive book. This is a large-format book (codex), made on solid parchment, decorated with 302 miniatures, plot-ornamental screensaver, a large number of artistic initials, drawings.

Since the twelfth century, the state-building and cultural-educational traditions of Kievan Rus had been continued by the Galicia-Volyn principality, on the territory of which (given that they suffered the least from the Horde conquerors) a centre of Ukrainian book-making was formed. The Galician-Volyn chronicle was created on these lands. It is distinguished by its dialogical structure, as well as the fact that it is dominated by descriptions of military events and much fewer church stories. One of the most valuable texts, the Galician Gospel of 1144, has also survived: "the 228-sheet manuscript created in the town of Krylos near Halych. The uniqueness of this monument lies in the fact that its creators were the first among the East Slavic scribes not only to copy pages from the previous manuscript but actually performed significant editorial work: they grouped the whole text into four separate parts, according to its authors - evangelists Matthew, Mark, Luke and John. Unfortunately, this ancient Ukrainian monument is now abroad - it was taken out of Halych in the middle of the 17th century. and now it is stored in one of Moscow's museums.",

The period of the $15^{\text {th }}-16$ th centuries became significant for the book business, as new centres of book writing appeared, and a gradual transition to much cheaper and more convenient material (paper) took place. All this contributed to the development of written literature and its promotion among consumers. Subsequently, the subject of books expanded, monastic book collections were formed (some of their copies were framed in gold, silver, etc.).

Regarding the repertoire of manuscripts of the $16^{\text {th }}-17$ th centuries, we observe the following distribution:

- liturgical books $75.5 \%$;

- books of religious and educational content $-10 \%$;

- biographical literature $-5.3 \%$;

- theological literature $-4.1 \%$;

- books of church law - 3\%;

- Bible books - $1.2 \%$;

${ }^{2}$ Derkach L. (2016) Ukrainska rukopysna knyha - dzherelo dukhovnoi kultury narodu [Ukrainian manuscript book - a source of spiritual culture of the people]. Dyvoslovo, no. 11, pp. 21-27. 
- secular books $-0.8 \% .^{3}$

Perhaps the most significant monument of Ukrainian manuscript art is the Peresopnytsia Gospel (1556-1561). The text, which was translated from the Church Slavonic language into "simple", close to the folk language of that time, is remarkable. The text covers four consecutive Gospels - from Matthew, Mark, Luke, John with a total volume of 960 parchment pages. The cover - oak boards framed in green velvet.

As for the frame, there is information that the upper cover was decorated with four silver corners with the image of the Evangelists and the middle with the image of the crucifixion of Christ. ${ }^{4}$ The special artistic value of the book consists of miniatures, screensavers, initials, which can rightly be considered the pride of the Ukrainian Renaissance. This monument is also very important in terms of language. It is clear evidence of the active use of the Ukrainian language in our church as early as the middle of the 16th century. It"s a fact that was previously silenced for ideological reasons. ${ }^{5}$

The beginning of book printing is characterized by special attention to the decoration of the title page. This is due to the desire of publishers, customers, authors to give the book an attractive appearance, so they considered the title, which begins the reader's acquaintance with the book, as the most important element of the publication as a whole. If we pay attention to the artistic decoration of the old prints' title pages of the seventeenth century by means of graphic art, the variety of compositional solutions, content, decorativeness, sophistication is impressive. As for the content of the artistic decoration of the titles, we find illustrations for stories from the Old and New Testaments; ornaments (floral, geometric). The work was performed by the best master engravers who possessed the technique of woodcarving and were determined by their knowledge in this matter - for example, they were able to reproduce the emotions of the depicted character not by facial expressions, but precisely found poses, movements, gestures. In general, a new stage in the history of culture begins with the printed book the art of book printing.

3 Fit L. (2014) Populiaryzatsiia vydannia zasobamy knyzhkovoho dyzainu [Popularization of the publication by means of book design]. Ukrainian information space, no. 2, pp. 225-232.

${ }^{4}$ Zapasko J. P. (1960) Ornamentalne oformlennia ukrainskoi rukopysnoi knyhy [Ornamental design of the Ukrainian manuscript]. Kyiv: Publishing House of the Academy of Sciences of the USSR.

${ }^{5}$ Derkach L. (2016) Ukrainska rukopysna knyha - dzherelo dukhovnoi kultury narodu [Ukrainian manuscript book - a source of spiritual culture of the people]. Dyvoslovo, no. 11 , pp. 21-27. 
The modern Ukrainian language uses the terms "hardcover", "hardback" "softcover" or "paperback" as synonyms (does not take into account the historical features of the meaning of concepts and semantic differences). Bibliology uses the term "hardcover" mainly when we are talking about old prints (usually before the 18th century.), which were made by hand and with certain technologies inherent in the relevant historical periods. The softcover is called a protective cover of a book made of thin cardboard, paper, film. Therefore, the art of creating hardcovers is of great interest, which is complicated by the turbulent events on the territory of Ukrainian lands (wars, uprisings, revolutions, etc.), which, in the end, caused irreparable losses to the book heritage. Certain features of the binding craft and the art of decorating hardcovers were caused by the conditions under which the Ukrainian lands were part of other states. The end of the 16th century is characterized by the use of new types of embossing tools, including knurling, cliche and mandrel techniques. There are also different types of embossing used in decorating the hardcovers of Cyrillic books. Blind embossing is common for the first half of the 16th century, and gold embossing began to be used in the middle of the century. The second half of the 16th century was defined by the use of plot clichés among Ukrainian frames. As for the subject matter of the images, both floral and geometric ornaments and complex plot compositions can be found in the middle of the hardcovers. Since the eighteenth century, the nature of the decoration of the hardcovers of secular books had been influenced by European fashion, but this did not affect the manner of design of the frames of books of religious content, including liturgical.

The chronology of the stages of development of the hardcover is connected with the main periods of the book's history:

1) the era of the manuscript codex, which is divided into ancient and medieval stages, when the book was made mostly for a specific customer (it was unique, as well as the hardcovers for it). In the Middle Ages, several types of hardcovers were formed: early medieval, Byzantine, Romanesque, Gothic, Oriental, and others. By the nature of the coating, they were completely covered and folded, by material - leather, fabric, etc.;

2) the epoch of book printing from its beginning (middle of the 15 th century) to the second third of the 19th century. (period of manual labour in the printing industry, in particular in the manufacture of hardcovers and paper). At this time, the demand for hardcovers increased sharply, as the number of books entering the market increased significantly, which, in turn, led to the introduction of mechanization and technological simplification of production and lower prices for books and frames. All this led to the emergence of a new professional group specializing in the manufacture of 
covers for the market. Prior to that, the need for hardcovers was met in small workshops (scriptories) at monasteries or universities;

3 ) the modern epoch of machine-factory polygraphic production development (second half of 19th - the beginning of 21 st century), when for mass production of books there was a need for the creation of new materials, technologies, in particular new ways and receptions of binding business. ${ }^{6}$

Ukrainian chronicles of the $17^{\text {th }}-18^{\text {th }}$ centuries are an invaluable source of Ukrainian history, which traces the path of understanding the phenomenon of spiritual culture of the Ukrainian Cossacks and the key to understanding the main features of the Ukrainian Baroque. As for the subject, the chronicles describe the causes and conditions of military conflicts between the Cossacks and the Polish nobility; religious disputes and clashes between Ukrainian Orthodox and Polish Catholics; activities and life of Ukrainian hetmans; life and heroic deeds of the Zaporozhian Cossacks; political events in Ukraine and abroad.

Speaking of focus, it is worth noting one detail. Namely, Cossacks chronicles focused all their attention on the people and events of the liberation war of the Ukrainian people, enthusiastically write in detail about Khmelnytsky, but other events are described in colloquial speech. Samiylo Velychko ends his chronicle in 1720, Samovydets - in 1734, G. Grabianka in 1710, although their lives do not end in these years (S. Velychko died not earlier than 1728, G. Grabianka - in 1737, Samovydets - RakushkaRomanovskyi - 1703. By 1734 the chronicle was proved by his "successors"). Cossack chronicles are based on a reliable account of events and high literary merits. Usually, in the chronicles there are references to government documents, hetman's universals, acts, charters, and the text is based on real documents of the time, the memories of contemporaries, the testimony of foreign chroniclers. The language of the chronicles is bookish, close to the vernacular.

The invention of printing brought to life a number of complex processes: carving punches, making (knocking out) matrices, casting of letters in matrices - font foundry business. Printing could be introduced in cities where there was a developed technique and skilled craftsmen worked. The availability of the necessary equipment and trained personnel contributed to the emergence of printing in the western lands of Ukraine. The state of ancient Ukrainian printing at that time made it possible not only to occupy an honourable place among the whole Slavic world but also to equate the technique of its publications with the peoples of Europe.

${ }^{6}$ Sokolov V. (2014) Z istorii knyzhkovoi opravy ta paliturnoho mystetstva [On the history of book frames and binding art]. Bibliotechna planeta, no 4, pp. 17-22. 
The Ukrainian book from the editions of Ivan Fedorov and Prince VasylKonstantin Ostrozkyi absorbed such artistic elements as decorativeness, saturation with forms of decor (screensavers, elm, some types of rubrication). As for the common European elements, we observe typesetting ornaments, macaron limbs, linear framing. The printing presses of Bishop Gideon Balaban of Lviv continued to enrich the repertoire of book design methods by introducing illustrative engravings in the early 17th century, as well as Renaissance book-specific initials depicting people and animals and mascaron limbs. ${ }^{7}$

Researchers determine that the printed books of the eighteenth century of a particular place have their own, unique features. For example, Kyiv prints are distinguished by woodcuts - high-quality reproductions of contemporary icons, skillfully prepared by the icon painters and engravers themselves; Chernihiv editions - beautiful book decoration; Pochaiv prints have an original artistic and technical design, unique forms of letters. Even more, the Pochaiv branch was distinguished by the refined elegance of the publications, which was achieved by the clarity of the fonts, the high quality of the paper, the perfection of the editorial preparation process and the thematic variety of the books.

However, the development of publishing (publishing books in Ukrainian) was significantly hampered by the Ems Decree of 1876, which prohibited the publication of Ukrainian books, except for historical documents, ethnographic materials, and original works of art permitted by censors. The result of government and censorship was the relocation of Ukrainian book printing outside the Russian Empire.

Book printing not only consolidated and disseminated new information but also contributed to the development of literacy in general, the formation, improvement of national and international literature. Book printing had many advantages, including:

- significant simplification of the printed form production (consisting of pre-prepared technical elements and parts);

- the possibility of repeated reuse of equipment;

- facilitating the process of accumulation and transfer of information;

- in book printing, the text reproduced in the form of hundreds and thousands of identical copies becomes the norm (for example, in the manual census, the scribes made their own changes to the text, which distorted the original);

7 Isaievych Ya. (2002) Ukrainske knyhovydannia: vytoky, rozvytok, problemy [Ukrainian book publishing: origins, development, problems]. Lviv: Instytut ukrainoznavstva imeni I. Krypiakevycha NAN Ukrainy, pp. 307-318. 
- increase in the number of textbooks, educational literature (educational institutions needed a large number of books; manuscripts, despite the mechanical reproduction of texts could not fully meet these needs).

\section{The Art of the Book in the 19th-21st Centuries: the Present}

Earlier we investigated that: "The culture of the book, which was based on the artisan method of production, gradually began to die out. This was actively facilitated by technical inventions in the paper and printing industries. The mechanization of processes in book publishing has allowed entrepreneurs not only to significantly increase the circulation of publications and reduce book prices but also to create market conditions for printed products, to produce the required number of popular publications. Spiritual and artistic qualities of the book, which for many years were a priority for book printers, in the early 19th century. started to recede into the background. ${ }^{8}$

The nineteenth century repeatedly changed the appearance of the book, depending on the evolution of printing technology, market demands, changes in artistic styles, and ultimately, fashion trends. For the book of the beginning of the century, the illustration is associated with the idea, content, and the design is dominated by rigour and restraint. The cover of the book is simple, usually grey, later it is replaced by coloured ones. All pictorial elements have stylistic features of classicism. The connection between art and book printing is becoming more noticeable than in previous times. Even more, the very concept of the art of the book acquires a new meaning. After all, the literature of the first half of the nineteenth century is understood as one of the factors of national self-identification - the ability to attest to their own traditions in art, literature, education in a complex of all signs and factors of development.

The unfavourable events of the second half of the 19th century, connected with the enslavement of the Ukrainian word in the Russian Empire, should have destroyed the national book and the culture of reading and the art of the book of Ukrainians. However, the above only led to the transfer of book publishing to the west, to Galicia, which later gave the Ukrainian book a repertoire and typological completeness and brought it on a par with developed European literature.

In general, the formation of national book publishing took place during the national and cultural revival of the country and during the rule of the Ukrainian Central Rada, the Hetmanate, the Directory, and the Ukrainian

\footnotetext{
${ }^{8}$ Karakoz O. (2018) Istoriia knyhy [History of the book]. Kyiv: Lira-K Publishing House, p. 323.
} 
People's Republic. It is at this time that the book became a source of formation of national and civic consciousness, the main tool for introducing new ideas into the public consciousness. Ukrainian-language socio-political, educational, and fiction literature was published, which was practised by more than 100 publishing houses (about 26 million books were published in 4 years). From 1917 to 1920, the country went from lifting all prohibitions of the tsarist government on publishing books in Ukrainian and censorship, creating private publishing houses, free sale of books to the nationalization of publishing, the introduction of censorship, banning free trade in printed publications.

During the revolutions, book printing in Ukraine was not determined by stability. A prominent figure in the Ukrainian book business, Yurii Ivanov (Mezhenko), notes that: "in March 1917, the "era of anarchic book production" began. The great, complex, and responsible demands of the revolution on Ukrainian books were partly underestimated and partly misunderstood by those sections of the petty bourgeoisie who were involved in book production." 9 The activities of publishers who lacked professionalism were determined by non-compliance with the culture of printing, which they neglected, inspired by rapid commercial success. For example, the publishing company "Drukar", whose employee (Heorhii Narbut) became one of the founding professors of the Ukrainian Academy of Arts. However, along with the demand for Ukrainian printed products, the pressure on printing houses and national publishing houses was increasing, that resulted in the liquidation of the national book trade. It is clear that the activities of the conglomerate from the remnants of various book publishing organizations could not be effective due to the destruction of structures and control.

The art of Ukrainian books was significantly negatively censored by the Soviet government, which increased its ideological pressure. Literature became more an appendage of ideology, ceasing to be literature. Certain standards were approved, the schemes according to which art served the revolution, aimed at building a new world. Thus, the cultural catastrophe of the 1930s destroyed a large layer of Ukrainian bibliography that had been built earlier. The publishing industry was under the close supervision of Ukrholovlit, which was established as a censorship body with the functions of supervising and controlling the publishing process.

Since the late 1950s, was an urgent need to raise the level of book art, to achieve the harmonious integrity and stylistic unity of the book as an art object. During the Soviet era, annual book art competitions were held, based on the results of which a catalogue of the winners' works was published.

\footnotetext{
${ }^{9}$ Mezhenko Y. (1928) Ukrainska knyzhka chasiv Velykoi revoliutsii [Ukrainian book of the Great Revolution]. Kyiv: Derzhtrest "Kyivdruk".
} 
There was a need for artists who would approach the book from the standpoint of its integral and non-standard design.

Book and graphics are inseparable concepts. Modern book graphics as an independent art form did not appear immediately. The first graphic images are known to us from the time when people lived in caves. And already today there are book illustrations, vignettes, screensavers, covers, dust jackets; creating a font drawing, general artistic design and technical design of the book. The book, having gone from a manuscript to a complex structured structure, has accumulated high examples of the art of illustration over the centuries. However, the strong shocks of book art in the twentieth century radically changed not only the attitude towards printed matter but also the writer's communication with the reader through a visual interpreter. Since then the book, having carried out the expansion of visual communications of all branches of culture, has fixed on an operational field of a modern society new concepts of the visual text, a sign, culture. Undoubtedly, the artistic image as the main category of creativity is a means of visual communication. Let's pay attention to the main differences between visual and verbal images:

- the speed of perception of the visual image is much higher (a moment to understand the picture and a few minutes to read the text);

- persuasiveness and clarity of the visual image determines the easy visual and logical perception;

- the image does not need translation;

- the emotional impact of the image on the reader is stronger than the text.

As for the art of the book, graphics are only a part, though a significant one. In order to understand the development of book drawing, fine, font or ornamental, it is important to know what place it occupied at one time or another and among the general range of artistic means of book art. Note that the picture in the book is not an independent phenomenon - it obeys the text, gives us the text, continues and complements it. No drawing can be included in a printed book without changes - it is given a printing form, the ability to reproduce. This technical feature plays an important role in the development of book art. The means and methods of drawing for a book are closely related to technical possibilities. The art of book graphics involves taking into account the peculiarities of the printing structure of the book, its unique nature as a cultural value and as a thing. The artist of the book must work in a clearly defined, predetermined size (format) because there are certain most rational standard formats. The look of the book is composed of many elements (from the cover to the typeface), there are also principles of developing light and shadow, volumes and means of composition. Therefore, all pictorial elements must be harmoniously combined not only with each 
other, but also with paper, typesetting strip, and so on. The main goal of the masters of modern graphics is to create individual, bright, unique art worlds because the book inevitably changes its social status.

Intensive development of the publishing and printing industry, taking place since the mid-1990s in the world, in particular in Ukraine, computerization and involvement in the design of books elements of computer graphics, the emergence of new types of books (electronic), international book fairs, professional competitions cause radical changes in the art of the book and its culture.

The end of the 20th - the beginning of the 21st century is determined by the increased attention and interest in the cultural heritage of previous epochs in the field of book design and artistic design. This leads to an increase in demand not only for higher quality book products but also for specialists book designers who can put into practice complex artistic and graphic ideas for modern publishing houses. Even more: "If previously only a printed book was available, now since the 1970s it has been possible to read texts on electronic devices. And the beginning of the 21 st century is characterized by the rapid growth of electronic technologies, which lead to the mass distribution of e-books, which are quickly occupying a leading position among connoisseurs of reading. There is a contrast between the art of print and e-book, which leads to competition and highlights the shortcomings of each. Therefore, today, when the main task of society is to promote reading, it is important to understand that any medium of information, the text is a valuable and undisputed participant in this process. ${ }^{10}$

In 2020, when the main goal of publishing houses, publishers is to sell their own book product, format, the volume of the book, materials from which it is made, the method of binding are of course extremely important factors that buyers pay attention to when choosing and buying a publishing product., but they are rather for regular customers of bookstores, who already understand the book quite well, from the standpoint of the reader, and in practice have experienced the benefits of a particular design. However, a large number of visitors to bookstores or exhibitions are rare guests of such institutions and, coming to the store, they do not focus on what they want, that is, are looking for a book that will interest, catch the eye, encourage you to pick it up and deploy. And in this case, the decisive role will not be played by the above factors, and the design of the book, both external and internal. Therefore, the priority of determining the material

${ }^{10}$ Karakoz O. O. (2019) Tradytsiina ta elektronna knyha cherez pryzmu problemy populiaryzatsii knyhy i chytannia [Traditional and electronic book through the prism of books and reading' popularization problem]. Issues in Cultural Studies, no 35, pp. 194-205. 
qualities in the creation of the book over the visual, above all, is necessary for publishers to calculate the economic feasibility of the book, and the design is created to involve the reader in buying the book directly.

The artistic means of the external design of different printed publications have a common basis. At the same time, the quality of covers depends on many factors and pictorial components, as almost inexhaustible possibilities of expression are inherent in the art of font, drawing, photography, computer processing, compositional options, the integrity of the overall solution. Recognizing the design as a means of self-representation, the following elements should be distinguished: cover design, the flyleaf and its design, all illustrative, schematic or other material that fills the content of the book and font. The cover as a generalizing factor and all its components, including font and illustrations, are factors of direct action. Secondary factors include all the other elements that a potential buyer sees as soon as he gets the book in his hands: the cover and the interior, i.e. the illustrative material and the font. Today, artists actively use the computer in their work, use an unlimited range of ready-made fonts, photographs, hand-drawn images, which ensure the creation of a coherent, meaningful composition and ensure the originality of the cover. ${ }^{11}$

Publishing begins to use not only traditional printing but also fundamentally new ways to promote products, the introduction of new electronic technologies that increase production capacity. In particular, the advanced capabilities of digital cameras, professional image processing packages, high-speed channels for transmitting information files of any size and high-power printing machines have made it possible to use stereo and zoom images as book illustrations for publication. Publishing begins to use not only traditional printing but also fundamentally new ways to promote products, the introduction of new electronic technologies that increase production capacity. In particular, the advanced capabilities of digital cameras, professional image processing packages, highspeed channels for transmitting information files of any size and high-power printing machines have made it possible to use stereo- and vario-images as book illustrations for publication.

Today there is a practice of simultaneous publication/sale of printed and electronic copies of one book. The transition of printed content to digital, the creation of e-books, which can be considered a unique and independent multimedia product due to a number of reasons, including:

- a large number of visual elements provides a better perception of information;

11 Fit L. (2014) Populiaryzatsiia vydannia zasobamy knyzhkovoho dyzainu [Popularization of the publication by means of book design] Ukrainian information space, no 2, pp. 225-232. 
- digital publications, in particular books, presented in the form of interactive mobile applications, not only give the publisher an instant response to the content, and the reader the opportunity to comment, distribute, communicate, but also allow to analyze reader behaviour.

Multimedia technologies open up completely new opportunities for the book industry, as they combine different media - text, video, photos, graphics, animation, sound, with which the art of the post-industrial book is formed. Earlier we outlined that: "The processes of virtualization and mediatization of the socio-cultural space have become a condition for the emergence of multimedia products. One of the types of such a product is a book trailer - a book visualization. In general, this is a video about a book, where information about the product is provided in any form. The book trailer can play a positive role as one of the ways to promote reading and attract attention to the book because literature and art are the leading elements of spiritual culture. ${ }^{12}$ Note that there are several classifications of book trailers, according to which they are divided into narrative content (presents the basis of the plot of the work); atmospheric (conveys the general mood of the book and the expected emotions of the reader); conceptual (translates the main ideas and general content orientation of the text). It is also known the distribution by the method of the visual embodiment of the text, according to which the book trailer can be a game (mini-film based on the book); non-game (slides with quotes, illustrations, photos, etc.), animation (cartoon on the book). A book trailer is a multimedia product that creates various elements - text (sounded, or that appears on the screen in the form of quotes, cues), images, video or audio. It combines literature and visual arts.

The interactivity of the book industry provides a method that allows the reader to engage in dialogue with the author through his work with a variety of technologies that allow you to activate the visual, tactile, verbal and audio channels of perception. Regarding interactive books created with the help of digital technologies, "A real discovery and previously unknown in the Ukrainian book space was the release of a series of 3D, 4D books with augmented reality (AR). Such books can be used as a separate element. However, if you download a free application to your own gadget, you will be able to see the pages of the book in a new way: the characters seem to come to life and the action takes place. Among the augmented reality fiction books are in demand "Alice in Wonderland", "The Nutcracker and the Mouse King" and others. Also, such interactive books have an "Audiobook" function, with which the book can be listened to in available languages. In

12 Karakoz O. O. (2019) Tradytsiina ta elektronna knyha cherez pryzmu problemy populiaryzatsii knyhy i chytannia [Traditional and electronic book through the prism of books and reading' popularization problem]. Issues in Cultural Studies, no 35, pp. 194-205. 
addition to fairy tales, fiction, the market for such books is filled with educational literature - encyclopedias, alphabets, books about animals, birds, books on physics, chemistry, anatomy, astronomy and more. Books of this type combine the traditions and innovations of book art."13

Today, book culture testifies to the expansion of the readership of the branches of knowledge of the surrounding world. The structure of reader requests is changing. Non-fiction literature is in demand (a genre of literature known since 1966, when Truman Capote's novel "In Cold Blood" was published, called by the author nonfiction novel). Distinctive features of this genre are a very realistic and documented accurate description of events and characters through the prism of figurative and aesthetic perception of the author. Interest in the genre of non-fiction has historical and economic justification because, in difficult times, people seek to escape from reality, waiting for fictional stories, and seek the truth tired of illusions in relatively simple times. This literature is characterized by the absence of fictional plots and characters, and the story usually goes through the personal worldview of the author, who uses various artistic and dramatic means. The specificity of the genre requires the author to be a recognized expert on the topic and scientifically and accurately describe all the events. It is interesting that literature of this type practically does not need advertising - there will always be those who are interested in tourism, cooking and so on.

Unknown so far, but no less interesting is the concept of "mash-up", which is the idea of combining two sources of information into a new product. That is, the authors of the mash-up style combine classic, previously known to us heroes in fantastic conditions, in the world of zombies, vampires and superheroes. Famous books in this genre are: "Pride and Prejudice and Zombies", "Abraham Lincoln: Vampire Hunter", by Seth Grahame-Smith "Sense and Sensibility and Sea Monsters" by Ben H. Winters, "Emma and the Vampires" by Wayne Josephson and others. Nowadays, it is becoming increasingly difficult to create a new product that would amaze and astonish the reader, but this synthetic genre, which seems to be invented for discerning booksellers, holds high positions and is actively developing even though the borrowing technique has long been known and used.

In the age of electronic media, the development of computer technology, there is a question about the fate of printed products, including books. One of our previous conclusions is that: "a distinctive feature of the current stage of development of society is that information exists both in traditional, printed form and in electronic form. Of course, books and other printed documents as

13 Karakoz O. O. (2019) Tradytsiina ta elektronna knyha cherez pryzmu problemy populiaryzatsii knyhy i chytannia [Traditional and electronic book through the prism of books and reading' popularization problem]. Issues in Cultural Studies, no 35, pp. 194-205. 
objects and means of recording and disseminating information accumulated by mankind have existed and will continue to exist. Modern information technologies have allowed not only to start large-scale translation of existing information into electronic form but also to ensure the creation of new information resources immediately in electronic form. This form of providing information, in addition to significantly accelerating communication processes, makes it possible to organize the processes of production, storage and dissemination of information at a qualitatively new level." 14

\section{CONCLUSIONS}

In the context of drastic social changes, the problems associated with transformations in culture become relevant for study, especially those aspects where traditional forms change not only their external attributes but also radically change the internal content. Examples of such changes are book culture and book art. Since the appearance of the first books, significant changes have taken place, depending on the level of culture and historical features of the region. The Ukrainian book is an integral part of world culture with its own unique and difficult history, the authority of which was gained under extremely unfavourable circumstances of development. The artistic design of the book is designed to educate the aesthetic tastes of the reader, to develop and improve the appearance of the publication, to make the inner world of the book brighter and juicier.

The art of the book is the unity of types of artistic and creative activity in relation to the conception, embodiment and reproduction of a book edition. The manuscript has not been printed during its existence, but its decoration and artistic content were extremely lush and rich in types, shapes, materials. The emergence of book printing gives rise to a modern understanding of the art of books as an independent branch of art - the process of creating a book as an art form and a printed publication. The printed book, together with the design, undergoes a complex process in which artistic creativity and technology (printing) are closely intertwined. At the same time, the art of books is a branch of creativity, an artistic activity aimed at creating a book as an artistic visual form of expression of a literary work, i.e., by means of graphics and printing creates a visual image of the text that requires high professional artistic skill.

A look at the art of creating books through the passage of time leads to the conclusion that the book was primarily a work of artistic thought of a particular region, a certain time plane. Today, when there are almost no

${ }^{14}$ Karakoz O. O. (2019) Tradytsiina ta elektronna knyha cherez pryzmu problemy populiaryzatsii knyhy i chytannia [Traditional and electronic book through the prism of books and reading' popularization problem]. Issues in Cultural Studies, no 35, pp. 194-205. 
restrictions for the book industry (neither in form nor in content) and information technology, computer programs and innovative tools come to the aid of man, the book becomes the property of all mankind and universal value.

\section{SUMMARY}

Today there is a need to create a systemic concept of the national idea as the basis of a united Ukraine, which is impossible without analysis and study of diversity, a set of manuscript and book heritage, publishing products, which is the source base for building this concept. Defining the peculiarities of the art of Ukrainian books promotes and comprehends the state-political and cultural unity of all processes of bibliology. The greatness and diversity in the composition and content of the manuscript and printed heritage of Ukraine should be involved in scientific circulation, actively promote the development of science, culture, education, state-building processes.

The purpose of the article is to study the peculiarities of the art of handwritten and printed books, from the eleventh century to the present, taking into account the achievements of world art and the realities of the information society. The scientific novelty is determined by the fact that the research expands and deepens the knowledge of the basic principles of the development of the art of the book in terms of comprehensive objectivity. Since the appearance of the first books, significant changes have taken place, depending on the level of culture and historical features of the region. The Ukrainian book is an integral part of world culture with its own unique and difficult history, the authority of which was gained under extremely unfavourable circumstances of development. The artistic design of the book is designed to educate the aesthetic tastes of the reader, to develop and improve the appearance of the publication, to make the inner world of the book brighter and juicier. A look at the art of creating books through the passage of time leads to the conclusion that the book was primarily a work of artistic thought of a particular region, a certain time plane. Today, when there are almost no restrictions for the book industry (neither in form nor in content) and information technology, computer programs and innovative tools come to the aid of man, the book becomes the property of all mankind and universal value.

\section{REFERENCES}

1. Derkach L. (2016) Ukrainska rukopysna knyha - dzherelo dukhovnoi kultury narodu [Ukrainian manuscript book - a source of spiritual culture of the people]. Dyvoslovo, no 11, pp. 21-27.

2. Dubrovina L. A. (2016) Rukopysna knyha ta rukopysno-knyzhna kultura: do spivvidnoshennia poniat $\mathrm{u}$ dzhereloznavchomu aspekti [Manuscript book and manuscript-book culture: the relationship of concepts 
in the source aspect]. Proceedings of the Biblioteka. Nauka. Komunikatsiia. Formuvannia natsionalnoho informatsiinoho prostoru (Ukraine, Kyiv, October 4-6, 2016) (eds. Popyk V. I., Dubrovina L. A., Horovyi V. M.), Kyiv: Natsionalna biblioteka Ukrainy imeni V. I. Vernadskoho, pp. 128-130.

3. Fit L. (2014) Populiaryzatsiia vydannia zasobamy knyzhkovoho dyzainu [Popularization of the publication by means of book design]. Ukrainian information space, no 2, pp. 225-232.

4. Frys V. Ya. (1998) Ukrainska rukopysna knyha XVI - pershoi polovyny XVII st.: problema reprezentatyvnosti ta vidtvorennia tsilisnosti [Ukrainian manuscript book of the 16th - first half of the 17th century: the problem of representativeness and reproduction of integrity]. Manuscript and book heritage of Ukraine, vol. 4, pp. 180-187.

5. Isaievych Ya. (2002) Ukrainske knyhovydannia: vytoky, rozvytok, problemy [Ukrainian book publishing: origins, development, problems]. Lviv: Instytut ukrainoznavstva imeni I. Krypiakevycha NAN Ukrainy. (in Ukrainian)

6. Karakoz O. (2018) Istoriia knyhy [History of the book]. Kyiv: Lira-K Publishing House. (in Ukrainian)

7. Karakoz O. O. (2019) Tradytsiina ta elektronna knyha cherez pryzmu problemy populiaryzatsii knyhy i chytannia [Traditional and electronic book through the prism of books and reading' popularization problem]. Issues in Cultural Studies, no 35, pp. 194-205.

8. Mezhenko Y. (1928) Ukrainska knyzhka chasiv Velykoi revoliutsii [Ukrainian book of the Great Revolution]. Kyiv: Derzhtrest "Kyivdruk". (in Ukrainian)

9. Sokolov V. (2014) Z istorii knyzhkovoi opravy ta paliturnoho mystetstva [On the history of book frames and binding art]. Bibliotechna planeta, no 4, pp. 17-22.

10.Zapasko J. P. (1960) Ornamentalne oformlennia ukrainskoi rukopysnoi knyhy [Ornamental design of the Ukrainian manuscript]. Kyiv: Publishing House of the Academy of Sciences of the USSR. (in Ukrainian)

Information about the author: Karakoz Olena orcid.org/0000-0002-7772-1530 $\mathrm{PhD}$ in History, Associate Professor Kyiv National University of Culture and Arts 36, Ye. Konovaltsia St., Kyiv, 01133, Ukraine 